\title{
Functional and Linguistic Characteristics of Donald Trump's Victory and Inaugural Speeches
}

\author{
Yulia Chanturidze \\ National Research University Higher School of Economics
}

\begin{abstract}
Correspondence concerning this article should be addressed to Settings Yulia Chanturidze, National Research University Higher School of Economics, Room 4340. 26 Shabolovka St., Moscow, Russian Federation, 119049.E-mail: chanturidze.yulia@gmail.com
\end{abstract}

\begin{abstract}
The current research is devoted to the comparative and contrastive analysis of Donald Trump's victory and inaugural speeches. Its objective is to identify their similarities and differences from the functional and linguistic points of view. The research consists of several stages. First, the two genres of discourse in question are defined. Then, an overview of their functions is provided. Next, the linguistic means of performing them are analyzed. The results of the research indicate that, due to their main goals, the genres in question express certain functions, which can be verbally expressed in various ways: in Trump's victory speech the inspirative function comes to the fore, while in his inaugural address the integrative and the performative functions dominate the other ones. Furthermore, in each case linguistic peculiarities correlate with the functions: in the victory speech the focus is on the 'greatness' of everything and everyone, whereas in the inaugural speech words connected with patriotism prevail, which is expressed mostly by means of personal pronouns. The results of the current research may function as a basis for further analysis of the genre of the victory speech, as it has not received enough scholarly attention yet, and of the peculiarities of Donald Trump's political discourse.
\end{abstract}

Keywords: political discourse, inaugural speech, victory speech, functional approach, Donald Trump, CDA

Political discourse has been the center of everyone's attention for decades. This may be explained by the fact that politics plays a crucial role in people's lives: the future of countries and the relations between them depend greatly on politicians' decisions. Political discourse rather often becomes a tool for manipulating people (Fairclough, 1989; CharterisBlack, 2005), expressing dominance or discrimination (van Dijk, 2013; Blackledge, 2005), and persuading and influencing people's opinion (Baranov, \& Kazakevich, 1991; Berezhnaya, 1986; Golodnov, 2008), which is why the identification and the definition of such methods of influence has gained special importance in modern linguistics. This can also be one of the reasons why, at present, several refereed journals publish research in this area (Discourse and Society; Journal of Language and Politics; Discourse, Context \& Media; and others).

According to Weiss (2003), discourse reflects the social, political, and cultural characteristics of its creators, which provides scholars with an opportunity to single out the main concepts and ideas of a person's worldview (Whorf, 1956; Maslova, 2001). Political discourse is presented by a diversity of genres (Chudinov, 2011). As there is no common definition of this term across disciplines and as a number of genre theories can be singled out, it is necessary to clarify its notion in the current research. Following Chilton and Schäffner, Critical Discourse Analysis (CDA) scholars, by 'genres' we mean "global linguistic patterns which have historically developed for fulfilling specific communicative tasks in specific situations" (Chilton \& Schäffner, 2002, p. 18). In other words, genres refer to types and structures of discourse which are meant to accomplish a specific purpose. This understanding has its roots in Bhatia's (1993) genre model, which emphasizes the importance of communicative purposes in shaping the genre itself. In his works he argues that if such purposes undergo a significant change, the genre changes as well.

The two genres of political discourse relevant to the current research are the victory speech and the inaugural speech. Both of them are similar to what Aristoteles called 'epideictic rhetoric'. He defined it as a solemn speech that is made in order to appeal to the audience's emotions. An epideictic speech is usually delivered at a certain important official occasion and marks a crucial moment in the history of a country or the whole world. This is the reason for its elevated 
style of lexis and syntax, the avoidance of clichés, and a wide use of rhetorical devices (Aristoteles, 1978).

The victory speech is the election night speech of the winning presidential candidate, which presents his/her first reaction to the election results. It serves as an intermediate stage between being a candidate for presidency and being inaugurated as the president. The main purposes of the victory speech are expressing gratitude to all those who have supported the candidate throughout the campaign and those who voted for him/her; reminding people of the key ideas of the presidential campaign, picturing the bright future ahead (Chanturidze, 2014); and displaying emotions aroused by the event (Gornostayeva, 2018; Lara, Márquez, \& Fuentes-Rodríguez, 2016, p. 130).

As far as the inaugural address is concerned, it has been part and parcel of the inauguration ceremony, and has been witnessed by a large audience since the inauguration of George Washington. Campbell and Jamieson define it as "an essential element in a ritual of transition in which the covenant between the citizenry and their leaders is renewed," in which "a newly elected president is invested with the office of the presidency" (Campbell \& Jamieson, 1990, p. 14). It does not contain much new information because there is no need for it, due to the focus of people's attention being on the event itself rather than on the words. Not going into detail, the newly elected president summarizes his/her promises made during the campaign, pursuing the goal of emphasizing the crucial character of the moment and linking it to the past and the future of the country. The inaugural speech is also aimed at reminding people of the unity and the greatness of their country (Sheygal, 2002) and at persuading the citizens of the country that the new president is fit for the political role and that he/she is entitled to achieve his/her objectives (Liu, 2012, p. 2409). Therefore, as the components of the inaugural address are set by tradition, it is the choice of words and the manner of speaking in front of the audience that matter most and that can let the speech be remembered for decades (Sheygal, 2002).

The tradition of speaking in public has been developing since ancient times, forming the set or rules of most effective rhetorical means. A significant number of American presidents and politicians in general have followed these rules so brilliantly that they are still renowned for their rhetorical skills (Campbell \& Jamieson, 1990; Lim, 2002; Harandi \& Jahantigh, 2017; Sameer, 2017; Alemi, Latifi, \& Nematzadeh, 2018).

The election of Donald Trump to the presidency in the USA has stimulated further interest in modern political discourse due to Trump's manner of speaking (Lamont, 2017) Thus, it is particularly essential to conduct a functional analysis of some samples of his discourse. In order to do this, his victory and inaugural speeches have been subjected for analysis in order to define the ways the functions are realized in them and to identify their peculiarities from the point of view of the linguistic means used.

Being analysis-driven, the study pursues the objective of answering the following research questions:

1. What linguistic and discursive means are used by Trump in order to express functions of the genre of the victory speech?

2. What linguistic and discursive means are used by Trump in order to express functions of the genre of the inaugural speech?

3. Is there any regularity in Trump's use of expressive means that may be typical of his discourse in general?

\section{Materials and Methods}

\section{Materials}

The research is based on the analysis of Donald Trump's following speeches:

1. The victory speech delivered in New York on the $9^{\text {th }}$ of November, 2016 on election night;

2. The inaugural address made in Washington, D.C., on the $20^{\text {th }}$ of January, 2017.

The choice is explained by the fact that both speeches signify the beginning of a new president's term and, thus, are meant to impress the audience in order to make people feel that their choice was the best possible. Even though both addresses are usually created by speechwriters, the genre of the victory speech allows improvisation to a certain extent due to the unofficial, more intimate character of the event, which contributes to defining the style of public speaking the president adopts.

In contrast to the victory speech, every word of the inaugural address is carefully thought out as it always draws the attention of not only the people within the borders of the country but also around the world.

\section{Methods}

To conduct this research, the following analytical methods were applied:

1. A functional analysis on the basis of valuable research on inaugural speeches conducted by a Russian linguist in the field of political discourse, Ye. I. Sheygal (2000), and previous research into the genre of the victory speech 
(Chanturidze, 2014). At this stage the linguistic means that help to perform these functions were identified and used as illustrative material for comparing and contrasting the genres in question.

2. A semantic analysis of the functionally active samples with the aim of identifying the implicit and explicit connotations imposed on them.

3. A critical discourse analysis of most prominent features, which contributes to identifying the speaker's ideology through analyzing the language peculiarities. As pointed out by Chilton (2004), the text itself does not contain its meaning because it is the broader social, discursive, and historical context that helps the listener make sense of what they hear. Therefore, discourse analysis was applied in order to define the context of the speeches and to illustrate how interdiscursive links can help to create such context.

\section{Procedure}

In order to perform the analysis, several research stages were singled out:

1. As the author was already familiar with the set of functions commonly fulfilled by the genres in question due to previous research, the first step consisted of reading the official transcripts of the speeches thoroughly to check whether the usual set of functions was present in the speeches. One more aim of this stage included the identification of linguistic means that explicitly or implicitly perform these functions.

2 . In the next stage, all linguistic means were grouped according to the function they carry out. Then, a semantic analysis was performed in order to identify the connotations these linguistic items can possess, which can contribute to expressing a certain message. This was done for every function that had been singled out. When it seemed necessary, numerical data in graphic form were introduced into the analysis to compare and contrast the speeches in question. Furthermore, the semantic context of the linguistic means was analyzed as collocations could help in understanding the colouring of a word.

3. The final step of the current analysis was directly connected with the author's 'background knowledge' as it is possible to identify interdiscursive links only in those cases when the researcher possesses rather profound cultural and historic knowledge of the field under analysis. In other words, one can analyze only those links which he/she can single out on his/her own and/or on the basis of articles on the subject. For example, if it is clear that the speaker emphasizes a certain word of his/her speech prosodically or repeats it several times, it is necessary to search for its connotations or other contexts in which this word had appeared before. Such links to other discourses could serve as a source of extra information for interpreting the speeches. Moreover, the extralinguistic context of speeches can be taken into account.

\section{Results and Discussion}

Functional peculiarities of various discourse genres can be investigated from two points of view. First, it is essential to see what language functions come to the fore in the genre under analysis. Then, more specific information can be received if several genres of the same type of discourse are compared and contrasted with each other. This explains why two genres of Donald Trump's political discourse have been subjected for analysis - the victory speech and the inaugural speech. They mark the end of the presidential campaign and the beginning of a presidential term.

As mentioned previously, each genre of discourse performs its own set of functions. Here we take Sheygal's research into the semiotics of political discourse in general and the American presidents' inaugural addresses in particular as the basis for the current analysis. It should be noted that the functions identified by Sheygal correspond to the genre characteristics of the inaugural address described by Campbell and Jamieson (1990). The same approach was applied in Chanturidze's research into the victory speech (2014), where functional characteristics of this genre were identified and described.

\section{The Integrative Function}

The first function to be mentioned is the integrative one, which consists in uniting people together (Sheygal, 2000). When analyzing samples of political discourse, it is crucial to pay attention to the image the speaker creates linguistically.

One thing that should be taken into consideration at this point is the use of personal pronouns as Wilson (1990) states, pronominal choices can reveal crucial information about the speaker and his/her attitude to the listener. The fact is that pronouns can contribute to expressing the opposition 'we' - 'they', which forms the basis of perceiving the world in categories (Abid \& Manan, 2017) and is typical of political discourse 
in general (Levenkova, 2011, p. 115). Within such an opposition the former component is usually marked as positive whereas the latter one is negatively coloured (Ma, 2012). It seems crucial to pay attention to this opposition as it is there where the methods of critical discourse analysis can help to reveal a more comprehensive picture of the peculiarities of Trump's victory and inaugural speeches.

In American political discourse the integrative function is most frequently realized with the help of the first person plural pronoun 'we' and its possessive form (Levenkova, 2011, p. 126), which means that the speaker identifies him/herself with a certain group of people, for example, members of the party or citizens in general.

The inclusive 'we' and its possessive form 'our' are found in both of Trump's speeches under analysis.

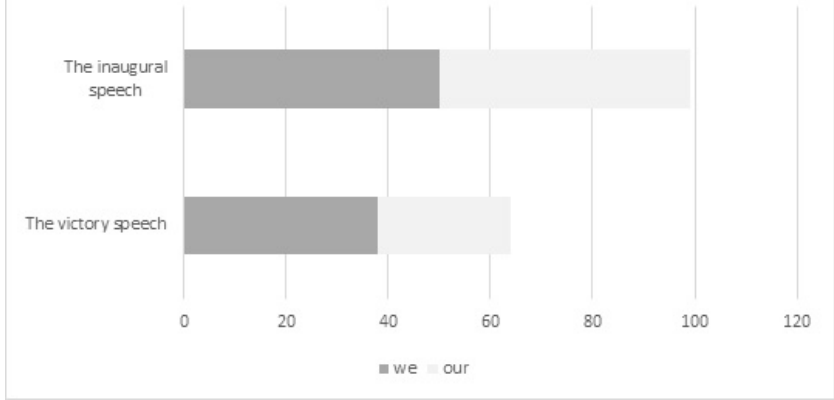

Figure 1. The number of uses of 'we' and 'our' in Trump's victory and inaugural speeches.

As seen in Figure 1, the inaugural speech contains almost twice as many instances as the victory speech does, which makes the idea of integration more emphatic. The following example, taken from the inaugural speech, can illustrate the extent to which the integrative function is fulfilled in it:

We will bring back our jobs. We will bring back our borders. We will bring back our wealth. And we will bring back our dreams. We will build new roads, and highways, and bridges, and airports, and tunnels, and railways all across our wonderful nation. We will get our people off of welfare and back to work - rebuilding our country with American hands and American labor. ${ }^{1}$

In this case, pronominal choice is accompanied by demographic nomination - 'American', which underlines the reliance on the country's inner

\footnotetext{
Trump, D. (2017, January 20). The inaugural address. Retrieved from https://www.whitehouse.gov/briefings-statements/the-inaugural-address/
}

resources excluding interference from the outside. In other words, preferring 'American hands and American labor', Trump implicitly underlines the difference between the American people and others, which again contributes to expressing the opposition 'we' - 'they'.

Moreover, the idea is often emphasized by a combination of the pronoun with such intensifiers as 'one', 'together', and 'united':

\section{I say it is time for us to come together as one united people. ${ }^{2}$ \\ We are one nation. \\ Together, We Will Make America Strong Again.

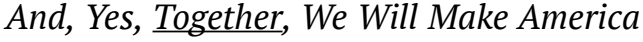 Great Again. ${ }^{3}$}

In addition, in his inaugural address Trump reminds people of the necessity of accepting the absence of differences between them by mentioning two children born in two completely different surroundings in America but looking into the same sky and dreaming about the same things, which is a rather common means of making public addresses more personalized and people-oriented, and by recalling military wisdom:

... our soldiers will never forget: that whether we are black or brown or white, we all bleed the same red blood of patriots, we all enjoy the same glorious freedoms, and we all salute the same great American Flag. ${ }^{4}$

In his victory speech, Donald Trump also expresses the same idea:

It is a movement comprised of Americans from all races, religions, backgrounds, and beliefs... ${ }^{5}$

However, in the former example more powerful and vivid imagery is used because, first, the reference to certain physical objects makes it easier for the listeners to imagine the situation described in the example (people bleeding, people saluting the flag) so there may not be any discrepancy in understanding the idea. Secondly, the topic of war is strong in its nature as, indeed, the differences between people do not matter when it comes to war. In other words, at this point people's 'backstage knowledge' (Chilton, 2004, p. 154) (especially that about recent wars) is activated.

\footnotetext{
2 Trump, D. (2016, November 9). The Victory Speech. The New York Times. Retrieved from https://www.nytimes.com/2016/11/10/us/ politics/trump-speech-transcript.html

3 Trump, The inaugural addres...

4 Ibid.

5 Trump, The Victory Speech..
} 
Being a crucial notion of critical discourse analysis, it comprises the knowledge and experience shared by people due to similarities in their background, culture, education, etc. (Kubryakova, 1997). As a result, all of the information gained from other discourses or experience and stored in the human mind is activated. This usually happens accidentally but may as well be used purposefully by proficient public speakers in order to influence the audience's attitude to the topic (Chanturidze, 2014a).

As far as one more implicit expression of the opposition 'we' - 'they' is concerned, it is essential to examine the following utterances taken from Trump's victory speech:

\section{... I congratulated her (H. Clinton) and her family on a very, very hard-fought campaign. <...> As I've said from the beginning, ours was not a campaign but rather an incredible and great movement, made up of millions of hard-working men and women who love their country and want a better, brighter future for themselves and for their family. ${ }^{6}$}

Here the focus is moved from 'them' being the people of other countries to 'them' being Hillary Clinton and the representatives of the Democratic Party. This is done using a careful choice of words. While calling Hillary Clinton's actions to win the election a 'campaign', which is defined by the Longman Dictionary of Contemporary English as 'a series of actions intended to achieve a particular result relating to politics or business, or a social improvement'7, to define his own undertaking, the speaker instead prefers the word 'movement', which means 'a group of people who share the same ideas or beliefs and who work together to achieve a particular aim's. Thus, this action is represented as the one to have united people, not as a purely personal desire to achieve a certain aim but as a collaboration. In contrast to how Hillary Clinton is presented, Donald Trump is portrayed as a leader chosen by people believing in the same things and pursuing the same ideals.

One more peculiarity of critical discourse analysis is taking interdiscursive links into account. Such links enable authors to interconnect discourses by appealing to the audience's 'backstage knowledge'. As defined by Blackledge, 'interdiscursivity refers to the intertextual relations of genres and discourses within a text' (Blackledge, 2005, p. 11). Such links contribute to the representation of a politician's worldview

\footnotetext{
6 Ibid.

7 Longman Dictionary of Contemporary English (LDOCE). Retrieved from https://www.ldoceonline.com.

8 Ibid.
}

(Demata, 2007). One of the most illustrative examples of interdiscursive links can be found in Trump's victory speech, where the use of the word 'movement' may activate an interdiscursive link to the civil rights movement, which helps to portray Trump as a person who is eager to defend the rights of his people and care about their future.

As a result, such a variety of means for expressing the idea of unity in the two genres under analysis shows that the integrative function is one of the most essential and powerful in political discourse.

\section{The Inspirative Function}

The next function of both the inaugural address and the victory speech that can be singled out is an inspirative one (Sheygal, 2000), which consists in inspiring the whole nation or a certain group of people to some action.

This function can be expressed, for example, by means of emphasizing the fundamental character of the current moment.

\section{I say it is time for us to come together as one united people. It is time.}

\section{That all changes - starting right here, and right now... \\ The time for empty talk is over. Now arrives the hour of action ${ }^{10}$.}

All examples adduced above show that the function is fulfilled with the help of two tools: the lexical items 'now' and 'time' and syntax (sentences are often short, incomplete, words are often repeated). Trump's syntax has been widely discussed since the beginning of his campaign. Some journalists still state that, in contrast to Barack Obama's speeches (Kienpointner, 2013), it is fairly hard to follow Donald Trump's thoughts and call his style 'word salad'11. Others believe that Trump's syntax resembles that of Twitter posts (Kreis, 2017; Sergeeva, 2017). However, there are some people, for example the prominent linguist George Lakoff, who explain this characteristic as a peculiarity of Trump's exceptionally elaborate style ${ }^{12}$. Therefore, these two tools of expressing the inspirative function can be seen collaborating with each other in these examples.

One more example deserves attention:

\footnotetext{
9 Trump, The Victory Speech...

${ }^{10}$ Trump, The inaugural address...

${ }^{11}$ Cilizza, C. (2015, September 15). An amazing Donald Trump word salad. The Washington Post. Retrieved from https://www.washingtonpost.com/news/the-fix/wp/2015/09/15/an-amazing-donaldtrump-word-salad/?utm_term=.6add3908d9b3

${ }^{12}$ Lakoff, G. (2016, August 19). Understanding Trump's use of language. George Lakoff blog. Retrieved from https://georgelakoff. com/2016/08/19/understanding-trumps-use-of-language/
} 
Today's ceremony, however, has very special meaning. Because today we are not merely transferring power from one Administration to another, or from one party to another - but we are transferring power from Washington, D.C. and giving it back to you, the American People. <...> January 20th 2017, will be remembered as the day the people became the rulers of this nation again ${ }^{13}$.

These words can function both as a means of unifying people with their president, who is chosen by them to present their interests and act on their behalf, and as a means to remind people that they too are responsible for the change because power is given not to a single man, i.e. the president, but to the whole nation. That is why, it is inferred, only if people take action can they achieve results and change their lives and their country for the better.

In comparison to other sub-genres of political discourse, the inspirative function is especially strong in electoral discourse as a new president's aim is to raise hope for a better future, for a change, and for proper solutions. People have voted for a certain candidate, which means that they are ready to entrust their lives to him as well as the future of their country and the values they have. Therefore, one of the biggest parts of both speeches is usually devoted to promises. In contrast to the programme offered by the candidate, this time the plans for the future are more general and are put in a more emotional form. The president does not go into detail because the goal is to make people believe they have made the right choice.

\section{We will double our growth and have the strongest economy anywhere in the world. At the same time, we will get along with all other nations willing to get along with us. We will be ${ }^{14}$. \\ We will bring back our jobs. We will bring back our borders. We will bring back our wealth. And we will bring back our dreams ${ }^{15}$.}

In order to underline the importance of a united effort, the speaker employs the structure 'we will' in both of his speeches (14 times in the victory speech and 24 times in the inaugural address), thus making people understand that without them he will not be able to achieve success and thus urging people to act alongside with him. This becomes an implicit call for action. The latter example is especially strong due to

\footnotetext{
13 Trump, The inaugural address...

${ }^{14}$ Trump, The Victory Speech...

15 Trump, The inaugural address...
}

the use of anaphora and parallelism in it.

The predecessors' experience, enhanced by the opportunities of the modern world and the new president's programme, is supposed to provide America with a chance to reach a new level of development. This idea is often expressed with words from the semantic field of novelty and change. It should also be noted that, as Donald Trump has been involved in the real estate business, it is possible to come across words related to this field in his speeches, but used metaphorically.

Working together, we will begin the urgent task of rebuilding our nation and renewing the American dream.

We must reclaim our country's destiny ${ }^{16}$.

From this day forward, a new vision will govern our land.

We will get our people off of welfare and back to work - rebuilding our country with American hands and American labor.

... we will rediscover our loyalty to each other ${ }^{17}$.

Apart from using different words belonging to the same field of use, Trump's tendency towards repeating the same words can be noticed. This can be well illustrated with the help of the Wordle created by Jonathan Feinberg in $2004^{18}$. This is a programme, which presents numerical data in the visual form of a cloud of words. While eliminating prepositions, conjunctions, pronouns, particles, and articles, the programme counts the number of instances of each word within a certain text uploaded to it and chooses its font size: the more frequently a word is used in the text, the more space it occupies in the word cloud.

Both Trump's victory and inaugural speeches were uploaded to the website of the programme so that the word clouds could be generated. The results are shown in Figure 2 and Figure 3 respectively.

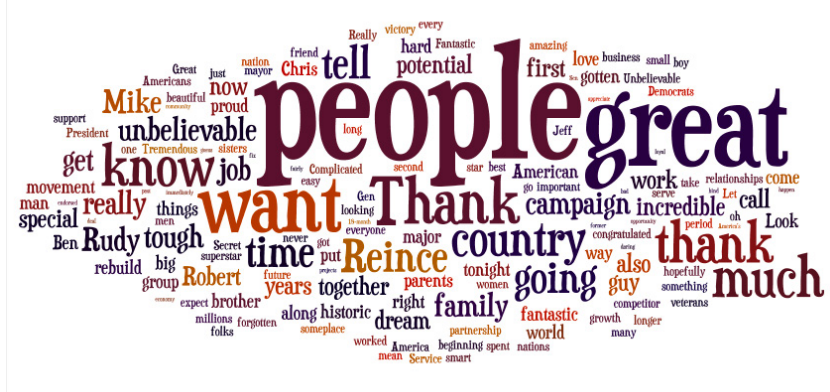

Figure 2. Word cloud of Trump's victory speech.

\footnotetext{
${ }_{16}$ Trump, The Victory Speech...

${ }^{17}$ Trump, The inaugural address...

${ }^{18}$ Feinberg, J. (2014). Wordle. Retrieved from http://www.wordle.net
} 
The same can be shown in a chart:

\begin{tabular}{lc}
\hline & WORD \\
People & USE \\
Great & 24 times \\
Want & 22 times \\
Country & 13 times \\
Time & 9 times \\
Unbelievable & 8 times \\
\hline
\end{tabular}

Figure 3. The chart of word use in Trump's victory speech.

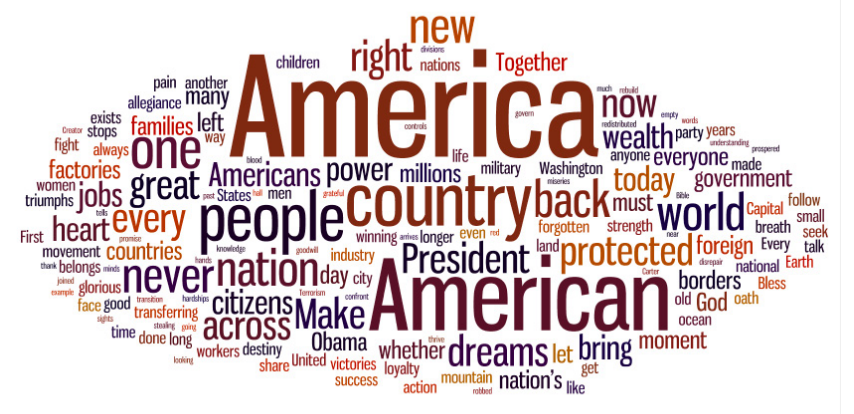

Figure 4. Word cloud of Trump's inaugural speech.

The same information can be presented in a chart:

\begin{tabular}{lc}
\hline WORD & USE \\
America & 18 times \\
American & 16 times \\
Country & 9 times \\
People & 9 times \\
Great & 6 times \\
\hline
\end{tabular}

Figure 5. The chart of word use in Trump's inaugural speech.

It is seen in Figure 2 and Figure 3 that the adjective 'great' appears in the victory speech the most often - 22 times to be more precise, whereas his next most popular adjective in this speech - 'unbelievable' appears only 7 times. This makes it possible to speak about Trump's idea of America being great as a country and people because one of the president's priorities is the protection of the image of the country in the world, the enhancement of its position, and its greatness in comparison to other countries. That is why one can frequently come across the adjective 'great' in Trump's victory and inaugural speeches. For example, in the former speech it is used 22 times, while in the latter one -6 times (Figure 5), which could be explained by a more formal character of the genre so the constant repetition of this word might seem inappropriate.

Since the adjective 'great' has a positive connotation, Donald Trump uses it to characterize America, veterans, his economic plan, future relations with other countries, his friends, his parents, and the work he is going to do. As a result, it may seem that the president divides the objects of the world into 'great' and 'not great' ones. Hence, the predominance of the positive adjective automatically sets the listeners' mood and defines the way they perceive the addresser's words (Sidiropoulou, 2018) since the more a word is repeated, the more eager people are to believe it (Lakoff, 2016).

At this point it should also be noted that the word 'great' appears to have a special meaning in Trump's discourse because it is even included in his campaign slogan - 'Make America Great Again', which he has been using since 2012, when it was registered. The phrase also serves as a subtitle of his book Time to Get Tough, first published in 2011 with the subtitle 'Make America \#1 Again' and then reissued in 2015 with a new subtitle. Since then Trump has been experimenting with the phrase, making slight alterations to fit the context. For example, in his acceptance speech at the Republican National Convention in 2016 he finished his address with the four syntactically parallel phrases, in which every new adjective evokes a positive association.

\section{We will make America strong again. \\ We will make America proud again. \\ We will make America safe again. \\ And we will make America great again! ${ }^{19}$}

Preferring words with positive connotations can also serve as a way of inspiring people: wealth, to win, friendship, to benefit, to thrive, to prosper ${ }^{20}$; potential, great, success, appreciate, wonderful, fantastic, unbelievable, incredible ${ }^{21}$ and so on. Furthermore, being more emotionally expressive, Trump's victory speech also contains a number of superlative adjectives, which contribute to increasing the degree of expressivity of this address: the best, the brightest, the strongest, the greatest, the fullest ${ }^{22}$.

Other words that stand out in the cloud of the victory speech (Figure 2) are 'people', 'country', and 'want'. The use of the former two is explained by the genre of discourse: the winner of election is talking to the people about the country they live in, whereas the latter one deserves attention. The preference of the verb 'want' over other possible equivalents of expressing the idea of desiring something may show that Trump's and common people's desires are plain

\footnotetext{
19 Trump, D. (2016a). Acceptance speech. Politico. Retrieved from https://www.politico.com/story/2016/07/full-transcript-donaldtrump-nomination-acceptance-speech-at-rnc-225974

${ }^{20}$ Trump, The inaugural address...

${ }^{21}$ Trump, The Victory Speech...

${ }^{22}$ Ibid.
} 
and simple and that he does not need any sophisticated words to express them.

As far as the word cloud of the inaugural address (Figure 4) is concerned, it shows several similarities with that of the victory speech. For example, it also contains the words 'country' and 'people' accompanied by 'America' and 'American', which cannot be avoided in this genre of discourse. Moreover, this corresponds with the peculiarities of the genre as in the inaugural speech the focus is on the country and its people, which evokes patriotic feelings.

One more effective stylistic means employed in both speeches consists in a contrasting description of the situation before the election and the future one. This is aimed at creating a more favourable attitude to the new president by showing that he/she is going to correct the mistakes of the former president, thus setting an example for all the people to follow.

\begin{abstract}
The forgotten men and women of our country will be forgotten no longer. <...> We will also finally take care of our great veterans... <...>. America will no longer settle for anything less than the best (2016). For too long, a small group in our nation's Capital has reaped the rewards of government while the people have borne the cost. Washington flourished - but the people did not share in its wealth. Politicians prospered - but the jobs left, and the factories closed. <...> That all changes - starting right here, and right now... <...> The forgotten men and women of our country will be forgotten no longer ${ }^{23}$.
\end{abstract}

\section{The Performative Function}

Apart from the functions mentioned above, a performative function should be mentioned as well. The role of this function consists of performing a concrete act in which the speaker is seen not as an individual but as the bearer of a certain social status (Sheygal, 2000).

Such a shift of focus, which differs the genres in question from general speaking in public, enables the speaker to alter the language and mention those topics that could not be included in the speech in other cases. For example, when delivering a victory speech, a former candidate for the presidency addresses the audience already as the winner of the election. The victory speech is the winner's first reaction to the results of the election. Therefore, the speaker can share his/her emotions, making the speech highly colourful and expressive. In contrast, the inaugural speech has

\footnotetext{
$\overline{{ }^{23}}$ Trump, The inaugural address...
}

a more formal character because of the official status of the event. That is why the inaugural speech is less expressive but better structured and thought over.

The victory speech marks a significant event - the victory of one of the candidates - and the beginning of a preliminary stage before the presidential term begins. The speech is made as soon as the results of the election day have been announced and summarizes the main points of the winner's campaign. At the same time, it may function as a rehearsal for the future inaugural speech as it anticipates what is going to be said in several months.

\section{I look very much forward to being your president... ${ }^{24}$}

The inaugural speech in its turn marks a momentous event in the history of a country - the official acceptance of the presidency by a new person. The role of the performative function in this genre of political discourse consists of providing the speaker with an opportunity to show his/her eagerness and readiness to occupy this official position.

$$
\begin{aligned}
& \text { The oath of office I take today is an oath of } \\
& \text { allegiance to all Americans. } \\
& \text { I will fight for you with every breath in my } \\
& \text { body - and I will never, ever let you down }
\end{aligned}
$$

The importance of this function is also defined by the absence of new information as the speaker just repeats the main promises. Therefore, the attention of the audience is shifted to the manner of speaking in public, to a so-called 'show' rather than to new information (Arkhangelskaya, 2018), so the addresser has an opportunity to show his/her mastery of rhetorical means, for example, syntactic parallelism and anaphora.

\section{We Will Make America Wealthy Again. We Will Make America Proud Again. We Will Make America Safe Again ${ }^{26}$.}

\section{The Declarative Function}

The next function that deserves attention is the declarative one. It consists of presenting a new president as the ruler of the country, the one who is going to establish new laws and implement new plans (Sheygal, 2000). In order to do this, a set of actions must be taken. Therefore, one can find statements about work and challenges in both of Trump's speeches under analysis.

\footnotetext{
${ }^{24}$ Trump, The Victory Speech...

${ }^{25}$ Trump, D. The inaugural address...

${ }^{26}$ Ibid.
} 
And I can only say that while the campaign is over, our work on this movement is now really just beginning. We're going to get to work immediately for the American people...27

We will face challenges. We will confront hardships. But we will get the job done ${ }^{28}$.

Another essential idea of the declarative function is connected with the president giving advice to the listeners about the responsibilities that they have as citizens. In Trump's inaugural address this is done with the help of modal verbs of obligation.

We must speak our minds openly, debate our disagreements honestly, but always pursue solidarity ${ }^{29}$.

As seen from the analysis, Donald Trump devoted much time of his public addresses to promoting the unity of the nation and proclaiming the greatness of the United States of America. All functions considered, it can be concluded that the genre of the victory speech and that of the inaugural speech have a number of functional peculiarities in common, although the degrees to which some functions are fulfilled in each of them may be different. Being inextricably connected with the functions, the aims of each genre exert considerable influence on the language that is chosen by the speaker. Therefore, there are more linguistic means that perform the integrative and the declarative functions in Donald Trump's inaugural address, whereas those carrying out the inspirative function prevail in the victory speech, allowing more room for emotions. The performative function is typical of both of Trump's speeches.

As far as the connotations of certain words and some interdiscursive links are concerned, it has become clear that with their help, Trump managed to create a positive image of himself while implicitly contrasting himself with his main opponent - Hillary Clinton.

\section{Problems and Limitations}

While conducting the analysis of any president's public speech, it should be kept in mind that leading politicians usually receive help with speechwriting. There are always professional speechwriters that either advise the speaker on the most suitable words and expressive means or write full speeches. That is why one can hardly know for sure which parts of the address were helped with and which were created by

\footnotetext{
${ }^{27}$ Trump, The Victory Speech...

${ }^{28}$ Trump, The inaugural address...

${ }^{29}$ Ibid.
}

the politician on his/her own. In the current article it will be assumed that, even though such information cannot be obtained, the politician is fully responsible for his/her words, which is why the peculiarities that are singled out are treated as characteristics of the politician's style, not the style of his/her speechwriters.

\section{Conclusion}

The overview of the functions of two genres of political discourse - that of Trump's victory speech and that of his inaugural speech - has shown the similarities and differences between them. From the functional point of view, the genres under analysis have a number of functions in common. However, they cannot be called identical as their aims define the set of functions and their positions on the scale of importance.

The main target of the victory speech is showing the winner's immediate reaction to the results of the election, finishing the campaign, summarizing the main points of the winner's plan, expressing gratitude, proving that people have made the right choice as a new president will lead people into a better world. Hence, the predominant function of this genre of discourse is the inspirative one. In addition, the victory speech is highly expressive so it is this genre of political discourse that shows the true character of a politician.

As far as the inaugural address is concerned, its main goal is mostly performative, i.e. announcing the beginning of a new president's term and being this beginning at the same time, but also integrative, as it is crucial for the new president to unify the people and show no traces of neglect or discrimination. The tradition of addressing the nation with an inaugural speech has a long history so its components and ideas are set in advance. Being an official speech, it is not so emotional, yet it is often impressive and remembered for decades.

\section{References}

Abid, R. Z., \& Manan, Sh. A. (2017). Constructing the 'self' and the 'other' in Bush's political discourse before and after the Iraq war (2002-2008). Journal of Language and Politics, 15(3), 710-726. doi: 10.1075/ jlp.15.6.03abi

Alemi, M., Latifi, A., \& Nematzadeh, A. (2018). Political and media discourse. Peoples' Friendship University of Russia: Linguistics, 22(2), 278-291. doi: 10.22363/2312-9182-2018-22-2-278-291 
Arkhangelskaya, I. B. (2018). “Temperature Regime” of American political discourse: From J. F. Kennedy to D. Trump. Communications. Media. Design, 3(1). Retrieved from https://cmd-journal.hse.ru/article/ view/7731

Bhatia, V. K. (1993). Analyzing genre: Language use in professional settings. New York, NY: Longman Publishing. Retrieved from https://books.google. ru/books?id=SSmsAgAAOBAI

Blackledge, A. (2005). Discourse and power in a multilingual world. Amsterdam / Philadelphia, Pennsylvania: John Benjamins Publishing Company. doi: $10.1075 /$ dapsac. 15

Chanturidze, Y. M. (2014a). Interdiskursivnost' kak chast' kognitivnogo podkhoda $\mathrm{k}$ kommunikatsii (Na primere pobednoy rechi B. Obamy, 2008) [Interdiscursivity as part of the cognitive approach to communication (On the basis if Barack Obama's victory speech, 2008)]. Yaroslavl Pedagogical Bulletin, 1, 140-144. Retrieved from http://vestnik. yspu.org/releases/2014_2g/27.pdf

Chanturidze, Y. M. 2014b. Pobednaya rech' buduschego prezidenta kak zhanr politicheskogo diskursa [Victory speech as a genre of political discourse]. Novosibirsk State University Bulletin, 6, 177-186. doi: 10.15293/2226-3365.1406.15

Charteris-Black, J. (2005). Politicians and rhetoric: The persuasive power of metaphor ( $1^{\text {st }}$ ed.). Basingstoke, Hampshire: Palgrave-MacMillan. doi: 10.1057/9780230319899

Chilton, P. (2004). Analysing political discourse. Theory and practice. London, UK: Routledge. doi:10.1093/ applin/ami016

Chilton, P., \& Schäffner, Ch. (2002). Introduction: Themes and principles in the analysis of political discourse. In P. Chilton \& C. Schäffner (Eds.), Politics as Text and Talk: Analytic Approaches to Political Discourse (pp. 1-41). Amsterdam/ Philadelphia, Pennsylvania: John Benjamins. doi: 10.1075/dapsac.4.03chi

Demata, M. (2017) "A great and beautiful wall”: Donald Trump's populist discourse on immigration. Journal of Language Aggression and Conflict, 5(2), 274-294. doi: 10.1075/ilac.5.2.06dem

Fairclough, N. (1989). Language and power. London, UK: Longman. doi: 10.1017/S0047404500016316

Golodnov, A. V. (2008). Ritoricheskiy metadiskurs: $\mathrm{K}$ opredeleniyu ponyatiya [Rhetorical metadiscourse: Defining the notion]. Pushkin Leningrad State University Bulletin, 2(13), 7-18. Retrieved from https://ib.herzen.spb.ru/text/ golodnov 104_77_87.pdf

Gornostaeva, A. (2018). Ironicheskiye metafory v politicheskom diskurse [Ironic Metaphors in Political Discourse]. Russian Journal of Linguistics, 22(1), 108-125. doi:10.22363/2312-9182-2018-22-

\section{1-108-125}

Harandi, M., \& Jahantigh H. (2017). Use of persuasive language to coax the audience: A study of John F. Kennedy and Barack Obama's speeches. International Journal of English Language and Translation Studies, 5(3), 129-136. Retrieved from http://www.eltsjournal.org/archive/value 5\%20 issue3/15-5-3-17.pdf

Kienpointner, M. (2013). Strategic maneuvering in the political rhetoric of Barack Obama. Journal of Language and Politics, 12(3), 357-377. doi: 10.1075/ ilp.12.3.03kie

Kreis, R. (2017). The "Tweet Politics" of President Trump. Journal of Language and Politics, 16(4), 607618. doi: 10.1075/ilp.17032.kre

Lara, E. A., Márquez A. C., \& Fuentes-Rodríguez C. (2016). Emotional argumentation in political discourse. A Gender-based Approach to Parliamentary Discourse, 68, 129-159. doi: 10.1075/ dapsac. 68

Lamont, M. (2017). Trump's electoral speeches and his appeal to the American white working class. British Journal of Sociology. Supplement S1, 68, 153-180. doi: $10.1111 / 1468-4446.12315$

Lim, E. T. (2002). Five trends in presidential rhetoric: An analysis of rhetoric from George Washington to Bill Clinton. Presidential Studies Quarterly, 32, 328348. doi:10.1111/j.0360-4918.2002.00223.x

Liu, F. (2012). Genre analysis of American Presidential inaugural speech. Theory and Practice in Language Studies, 2(11), 2407-2411. doi:10.4304/ tpls.2.11.2407-2411

Sameer, I. H. (2017). Rhetorical and linguistic analysis of Bush's second inaugural speech. Advances in Language and Literary Studies, 8(1), 44-50. doi: 10.7575/aiac.alls.v.8n.1p.44

de Saussure, L. (2005). Manipulation and cognitive pragmatics. In L. de Saussure \& P. Schulz (Eds.), Manipulation and Ideologies in the Twentieth Century (pp. 113-145). Amsterdam, the Netherlands: John Benjamins. doi: 10.1075/dapsac. 17.08all

Sergeeva, D. S. (2017). Self-presentation and discreditation - The key strategies of the preelection political discourse (As exemplified in the pre-election tweets of D. Trump and H. Clinton). Izvestiya Yužnogo Federal'nogo Universiteta: Filologicheskie Nauki, 3, 75-83. doi: 10.23683/19950640-2017-3-75-83

Sidiropoulou, M. (2018). Shaping public view: Critical media literacy through English-Greek translated press headlines. Journal of Language and Politics, 17(4), 511-532. doi: 10.1075/ilp.17018.sid

van Dijk, T. A. (2013). Diskurs i vlast' [Discourse and power]. Moscow, Russia: Librokom Publisher. doi: $\underline{10.1177 / 17504813090030020503}$

Weiss, G. (2003). Introduction: Theory, 


\section{FUNCTIONAL AND LINGUISTIC CHARACTERISTICS OF DONALD TRUMP'S SPEECHES}

interdisciplinarity and critical discourse analysis. In G. Weiss \& R. Wodak (Eds.), Critical Discourse Analysis: Theory and Interdisciplinarity (pp. 1-35). London, UK: Palgrave. doi:10.1057/9780230288423 Whorf, B. L. (1956). The relation of habitual thought and behavior to language. In J. B. Carroll (Ed.), Language, Thought, and Reality: Selected writings of
Benjamin Lee Whorf (pp. 134-159). Cambridge, MA: MIT Press.

Wilson, J. (1990). Politically speaking. The pragmatic analysis of political language. Basil Blackwell, Oxford/Cambridge/Massachusetts, Oxford: Basil Blackwell. doi:10.4236/apd.2013.21006 